\title{
Analysis of the Increased Iron Content on the Corrosion Resistance of the AlSi7Mg0.3 Alloy Casting
}

\author{
Jaroslava Svobodova ${ }^{1}$, Milan Lunak ${ }^{2}$, Michal Lattner ${ }^{1}$ \\ ${ }^{1}$ Faculty of Mechanical Engineering, J. E. Purkyně University in Ústí nad Labem, Pasteurova 7, 40096 Ústí nad Labem. \\ Czech Republic. E-mail: jaroslava.svobodova@ujep.cz, michal.lattner@ujep.cz \\ ${ }^{2}$ Beneš a Lát a.s., Tovární 463, 28914 Poříčany. E-mail: milan.lunak@benesalat.cz
}

\begin{abstract}
Aluminium alloys are, due to their properties, an important part of all shaped castings made especially for the aerospace and automotive industry. One of the widely used alloys, for the production of castings in the automotive industry, is the AISi7Mg0.3 alloy. In the experiment, which is the content of this paper, two castings from AISi7Mg0.3 alloy were tested. Iron is a common contaminant in aluminium alloys and its content in the alloy is increased by the use of secondary aluminium alloys or by various causes during the production process itself. In the experiment, the corrosion resistance of castings was evaluated (in one of them the increased Fe content) under the specified conditions in the corrosion chamber with salt mist. Corrosion properties were evaluated using confocal laser microscopy. Based on the results of the microscopic analysis, the relevant conclusions were formulated. From the experiment, it is evident that the increased iron content $(0.319$ [wt. \%]) does not, in this case, affect the corrosion resistance of casting.
\end{abstract}

Keywords: $\mathrm{AlSi} 7 \mathrm{Mg} 0.3$, Increased iron content, Corrosion resistance, Microscopic analysis

\section{Introduction}

Al-Si based alloys are representatives of the most widely used types of foundry aluminium alloys. The combination of suitable mechanical and foundry properties allows a great variety of applications in this field. Castings made of these alloys find their application, especially in the automotive, aerospace and food industry. The properties of Al-Si aluminium alloys are greatly influenced by their chemical composition. [1, 2]

Examining of these alloys has led to the discovery of two basic groups of elements. The first group are elements that are intentionally added to the alloy melt. They are so-called alloying elements, e.g. Ni, Cr, Mg, Mn, Zn. The additive elements favourably influence some properties of the type of alloy, e.g., increase the mechanical properties, improve machinability, affect the metal structure, are an important part in terms of heat treatment, or reduce the adverse effect of some accompanying elements. The content of the additive elements is usually lower than that of the main additive element. The additive elements may be several in the alloy at the same time. [3, $4,13]$

The second group of accompanying elements are the so-called undesirable elements (admixtures). These elements are not intentionally added to the alloys. In particular, feedstocks are the source of the accompanying unwanted elements, or they come into the alloy during the melting process from the lining, from the used melt jigs and from the handling means. A major source of impurities is mainly the remelting of aluminium scrap. A significant problem with many unwanted companion elements is the difficult way to eliminate the adverse effects on aluminium alloys or their complete removal from the alloy. In the vast majority of them, they cannot be removed in the foundry conditions and their content reduced to an acceptable limit. The proportion of unwanted elements in aluminium alloys is increasing due to the ever-increasing waste recycling pressure. The high iron content is currently a considerable problem. The most widely used method of suppressing the adverse effect of iron in an aluminium alloy is to dilute the melt with pure aluminium. However, this method makes the alloys rather expensive. Therefore, the industry is still looking for efficient and economically acceptable ways to eliminate the effects and the presence of undesirable elements such as iron. [5-7]

Iron has low solubility in aluminium alloys and is excreted as intermetallic phases. The intermetallic phases are, for example, $\mathrm{FeAl}_{6}, \mathrm{FeAl}_{3}, \mathrm{Fe}_{2} \mathrm{SiAl}_{8}, \mathrm{AlFeMnSi}$ and $\mathrm{Al}_{5} \mathrm{FeSi}$. With iron content above 0.6 [wt. \%] begins to predominate in the formation of brittle $\mathrm{Al}_{5} \mathrm{FeSi}$ phases, which are secreted in the interdendritic spaces of the hypoeutectic silumins (Fig. 1). These phases substantially reduce the plastic properties of the material. $[5,8,12]$

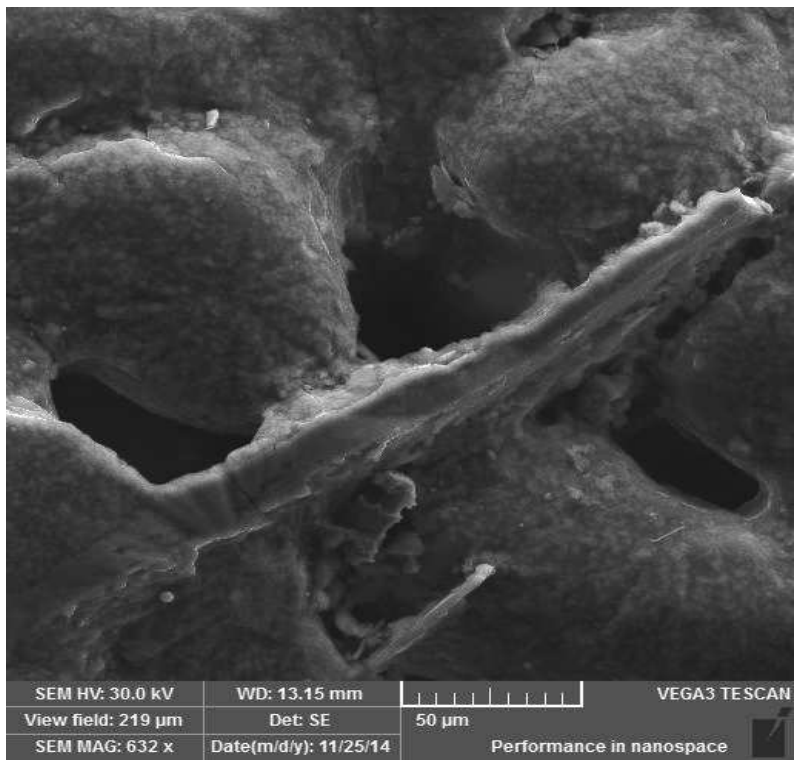

Fig. 1 Interdendritic spaces of the AlSi12NiMgCu alloy filled with rough phases $\mathrm{Al}_{5} \mathrm{FeSi}$ (Fe content 0.82 [wt. \%]) [9] 
Aluminium and its alloys have many specific corrosion properties. One of these properties is a high passivation ability, high susceptibility to point corrosion in the chloride environment and crystalline corrosion anisotropy. Aluminium alloys are also prone to intercrystalline corrosion and corrosion cracking. Specific forms of corrosion mentioned above (Fig. 2: a) spot corrosion, b) tunnel effect in spot corrosion, c) transcrystalline corrosion by layers, d) intercrystalline corrosion, e) cracks at corrosion cracking, f) layer corrosion cracking) related with conditions in which the passive state is breached. $[4,10]$
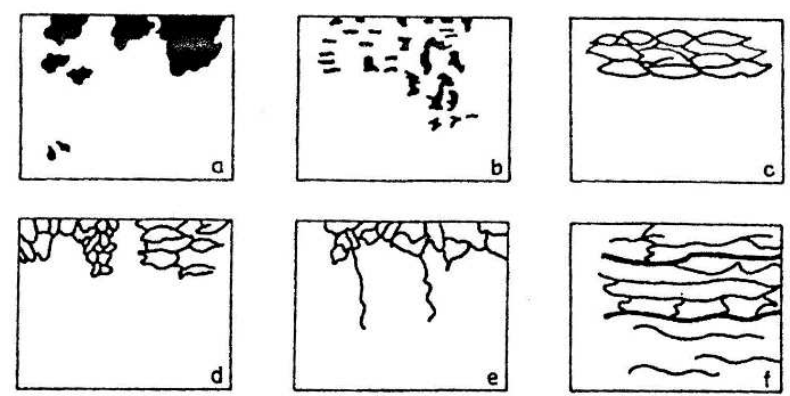

Fig. 2 Basic types of specific corrosion attack of Al alloys [4]

The passive state of aluminium (Fig. 3) is related to the formation of oxidic and hydroxidic products of corrosion, the solubility of which is dependent on the $\mathrm{pH}$ of the environment. Minimum solubility was determined at $\mathrm{pH}$ $=5$. $[3-5]$

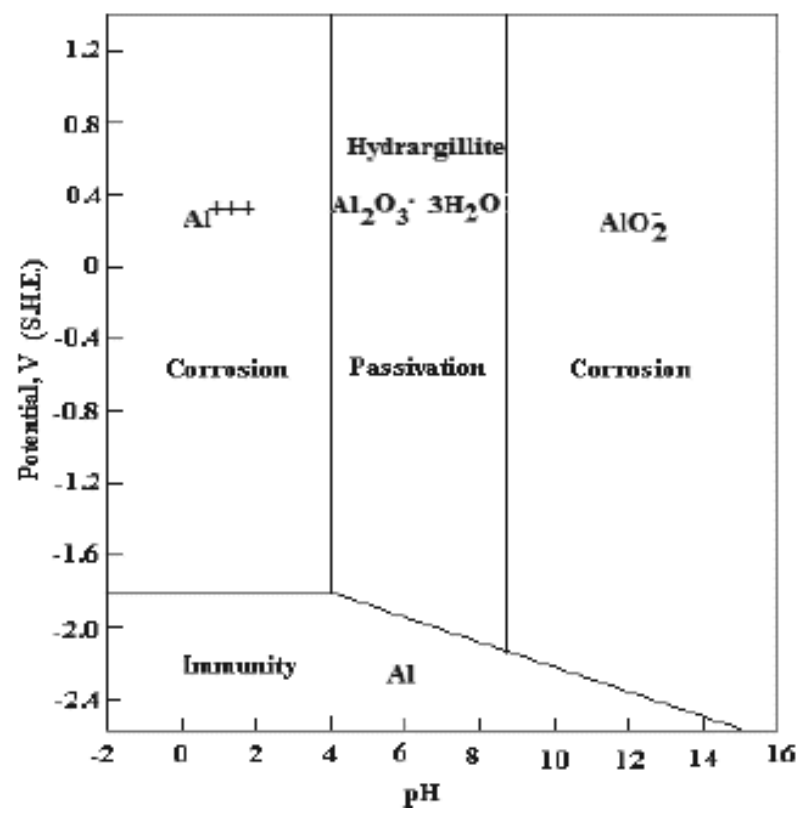

Fig. 3 Pourbaix diagram for aluminium

Aluminium is resistant to atmospheric conditions, where a protective layer of $5-20 \mu \mathrm{m} \mathrm{Al}_{2} \mathrm{O}_{3}$ is formed even in the presence of $\mathrm{SO}_{2}$. This layer resists the highest concentrations of $\mathrm{HNO}_{3}$ and diluted $\mathrm{H}_{2} \mathrm{SO}_{4}$ solutions. [4] Figure 4 shows the dependence of corrosion on the $\mathrm{HNO}_{3}$ concentration at different temperatures. The maximum corrosion rate for aluminium in this environment is $30 \%$
$\mathrm{HNO}_{3}$.

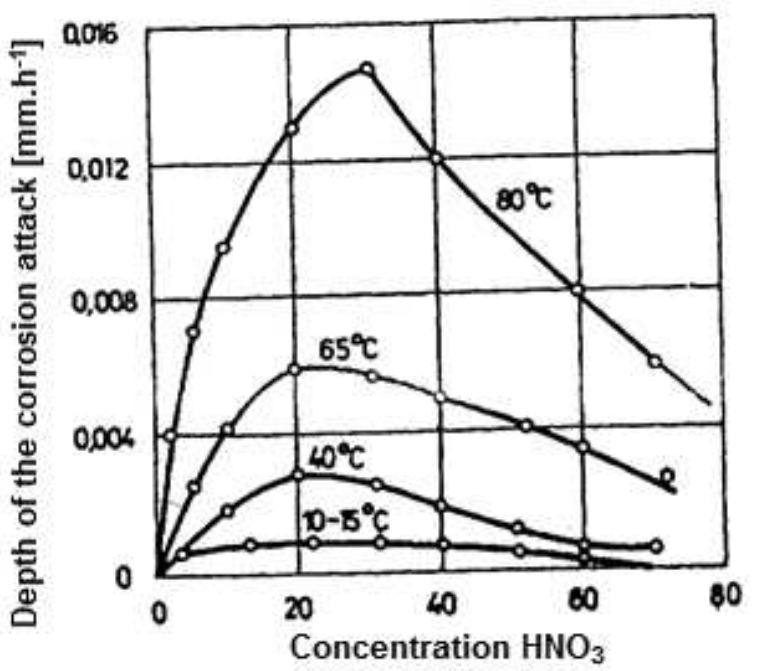

Fig. 4 Dependence of Al corrosion rate on temperature and $\mathrm{HNO}_{3}$ concentration [4]

The dependence of $\mathrm{Al}$ corrosion rate on $\mathrm{H}_{2} \mathrm{SO}_{4}$ concentration is shown in figure 5. Aluminium in $80 \%$ sulfuric acid achieves the lowest corrosion resistance. Aluminium is non-resistant to both organic and inorganic reducing acids.

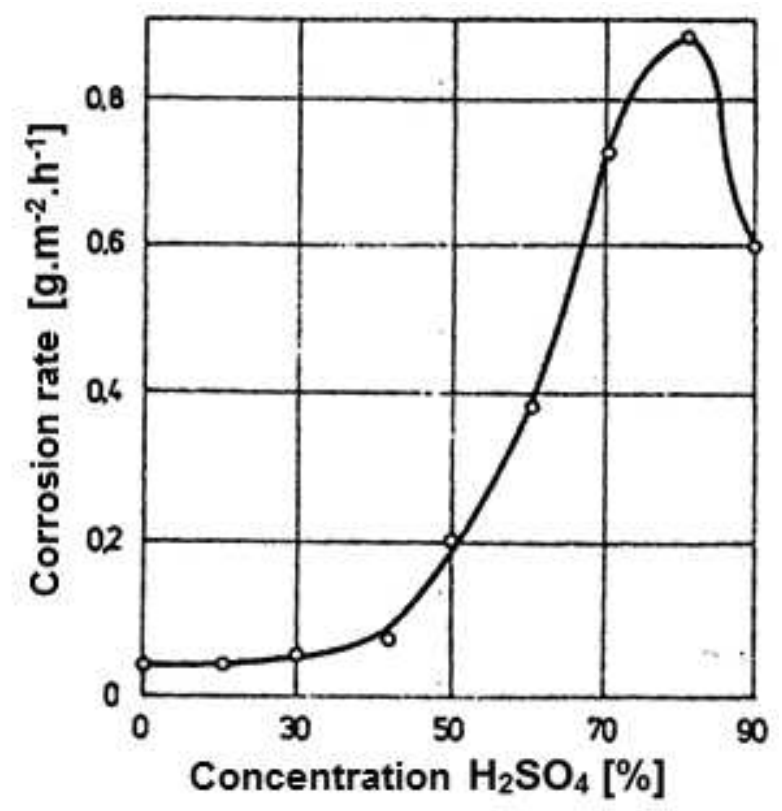

Fig. 5 Dependence of Al corrosion rate on temperature and $\mathrm{H}_{2} \mathrm{SO}_{4}$ concentration [4]

AlSi7Mg0.3 (EN AC-42100) is a hypoeutectic aluminium alloy that features good casting properties, good corrosion resistance, and machinability. Furthermore, this alloy has a high resistance to hot cracking. The table below shows the chemical composition of the aluminium alloy for AlSi7Mg(Fe) castings according to ČSN EN 1706 Aluminum and aluminium alloys - Castings - Chemical composition and mechanical properties for $\mathrm{Al}-\mathrm{Si}-\mathrm{Mg}(\mathrm{Fe})$ alloys. 
Tab. 1 Chemical composition of AlSi7Mg(Fe) alloy according to ČSN EN 1706

\begin{tabular}{|c|c|c|c|c|c|c|c|c|c|c|}
\hline \multicolumn{2}{|c|}{ Alloy designation } & \multicolumn{7}{c|}{ Element content [wt. \%] } \\
\hline $\begin{array}{c}\text { Alloy } \\
\text { group }\end{array}$ & $\begin{array}{c}\text { Numerical des- } \\
\text { ignation }\end{array}$ & $\begin{array}{c}\text { Chemical } \\
\text { designation }\end{array}$ & $\mathrm{Si}$ & $\mathrm{Fe}$ & $\mathrm{Cu}$ & $\mathrm{Mn}$ & $\mathrm{Mg}$ & $\mathrm{Zn}$ & $\mathrm{Ti}$ & $\mathrm{Al}$ \\
\hline AlSi7Mg & EN AC - 42100 & $\begin{array}{c}\text { EN AC- } \\
\text { AlSi7Mg0.3 }\end{array}$ & $\begin{array}{c}6.5- \\
7.5\end{array}$ & $\begin{array}{c}0.19 \\
(0.15)\end{array}$ & $\begin{array}{c}0.05 \\
(0.03)\end{array}$ & 0.10 & $\begin{array}{c}0.25-0.45 \\
(0.30-0.45)\end{array}$ & 0.07 & $\begin{array}{c}0.25 \\
(0.18)\end{array}$ & $\begin{array}{c}\text { resi- } \\
\text { due }\end{array}$ \\
\hline
\end{tabular}

The older standard ČSN 424332 states that this particular alloy can have a Fe content of up to 0.80 [wt. \%] (as stated in the ČSN 424332 standards in the case of castings cast into metal moulds).

The literature refers to the Fe content of aluminium alloys as follows: "Iron is always present in aluminium. It is the dominant ingredient in commercially produced alloys. Often it is added inadvertently using steel tools for melting and casting, or by mixing iron or rust into the molten material. In some alloys, iron is added intentionally, although its content usually does not exceed 1 [wt. $\%$ ]. Among the most common alloys are $\mathrm{Al}-\mathrm{Cu}-\mathrm{Ni}$, where iron is added to increase the high -temperature strength; low-alloyed Al-Mg alloy, in which iron plays a key role in the reduction; Al-Fe-Ni alloys to which Fe is added to reduce corrosion in vapours at elevated temperatures, and a recently developed conductive material, where $\mathrm{Fe}$ is allowed to reinforce the alloy without substantial loss of conductivity. $[3,6]$

The definition of corrosion implies that it is caused by spontaneous processes between the material and the environment. The chemical composition of the alloy also influences the corrosion resistance.

The patterns that describe the corrosion kinetics, especially in long-term aluminium applications, are not yet fully known, leading to the need to rely on practical tests or empirical experience to assess the corrosion of this particular material in specific electrolytes.

Generally, the highest corrosion resistance has a highly pure metal. Admixtures in technically pure aluminium $\mathrm{Na}, \mathrm{Ce}, \mathrm{Co}, \mathrm{Pt}, \mathrm{Ag}, \mathrm{Th}, \mathrm{V}, \mathrm{Hg}, \mathrm{Ca}$, in some cases $\mathrm{Cr}, \mathrm{Sn}$, and $\mathrm{Cd}$ reduce its corrosion resistance because, with the exception of $\mathrm{Mn}$, they are all cathodes. The positive effect of $\mathrm{Mn}$ lies in the formation of $\mathrm{MnAl}_{6}$, which binds $\mathrm{Fe}$ to intermetalide $(\mathrm{MnFe}) \mathrm{Al}_{6}$. This intermetalide produces slag during the melting process, which eliminates the negative influence of $\mathrm{Fe}$ on corrosion of $\mathrm{Al}$. For corrosion resistance, it is crucial for technically important aluminium alloys (ie AlSi7Mg0.3) whether they are alloys with or without $\mathrm{Cu}$. Copper-free aluminium alloys have practically the same corrosion properties as pure aluminium 99.5 [wt. \%]. These include Al-Mn, Al-Mg-Mn, $\mathrm{Al}-\mathrm{Mg}, \mathrm{Al}-\mathrm{Si}-\mathrm{Mg}, \mathrm{Al}-\mathrm{Zn}-\mathrm{Mg}$ alloys. Copper alloys usually have a $\mathrm{Cu}$ content of $2.5-4.5$ [wt. \%]. [3, 5, 6, 11, 13]

Tab. 2 Chemical composition of casting No. 1 [wt. \%]

\begin{tabular}{|c|c|c|c|c|c|c|c|c|c|}
\hline $\mathrm{Si}$ & $\mathrm{Fe}$ & $\mathrm{Cu}$ & $\mathrm{Mn}$ & $\mathrm{Mg}$ & $\mathrm{Cr}$ & $\mathrm{Ni}$ & $\mathrm{Zn}$ & $\mathrm{Ti}$ & $\mathrm{Al}$ \\
\hline 7.373 & $\mathbf{0 . 1 6 9}$ & 0.0058 & 0.054 & 0.278 & 0.0015 & 0.0037 & 0.015 & 0.160 & 91.89 \\
\hline
\end{tabular}

Tab. 3 Chemical composition of casting No. 2 [wt. \%]

\begin{tabular}{|c|c|c|c|c|c|c|c|c|c|}
\hline $\mathrm{Si}$ & $\mathrm{Fe}$ & $\mathrm{Cu}$ & $\mathrm{Mn}$ & $\mathrm{Mg}$ & $\mathrm{Cr}$ & $\mathrm{Ni}$ & $\mathrm{Zn}$ & $\mathrm{Ti}$ & $\mathrm{Al}$ \\
\hline 6.609 & $\mathbf{0 . 3 1 9}$ & 0.0095 & 0.063 & 0.309 & 0.0049 & 0.0049 & 0.0061 & 0.145 & 92.45 \\
\hline
\end{tabular}

The basic corrosion properties of $\mathrm{Al}$ alloys are given by the criteria of their passive state and the critical values of the corrosion process. An important parameter in the question of corrosion resistance is the corrosion potential of the alloy: by the alloy $\mathrm{Al} 99.95$ is $\mathrm{E}_{\mathrm{cor}}=-520[\mathrm{mV}]$, by the alloy $\mathrm{Al}$ with a percentage of iron $0.2-1.1$ [wt. \%] is $E_{\text {cor }}=-510[\mathrm{mV}]$ which is a very small difference in corrosion potential. [3]

The aim of this paper is to verify experimentally and then evaluate the corrosion resistance of castings made of the alloy AlSi7Mg0.3 at increased Fe content of this alloy.

\section{Experiment}

\subsection{Experimental samples and corrosion test}

In the experiment, two samples of castings were tested (Fig. 6), which are used as parts of the car washer in the final use. The reason for corrosion testing was the suspicion of reducing the corrosion resistance of the part due to the higher content of Fe compared to the standard value of the element content. The part is neither statically nor dynamically loaded. No influence or change in the machining process was observed during the processing of the part. The castings were made by low-pressure casting into a metal mould and heat treated with T6 (heat treatment consisting of annealing and artificial ageing). Its aim is to obtain optimal strength and plastic properties.

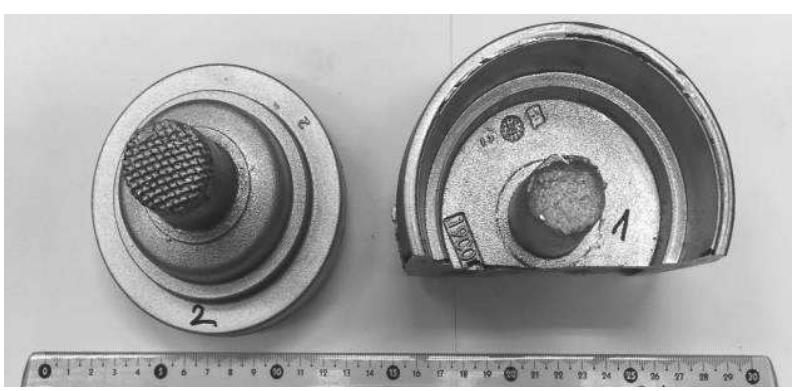

Fig. 6 Experimental samples of AlSi7Mg0.3 castings

The chemical composition of the castings is shown in tables 2 and 3. Chemical analysis was performed using a Q4 Tasman optical emission spectrometer. 
The content of $\mathrm{Fe}-0.169$ [wt. \%] was measured by the casting No. 1 and increased content of Fe -0.319 [wt. $\%$ ] by the casting No. 2 .

The castings were placed in the corrosion chamber and the corrosion test conditions were determined according to ČSN EN ISO 9227 (038132) Corrosion tests in artificial atmospheres - Salt spray tests, load time was set at $480 \mathrm{~h}$ (customer requirement for which castings were made), temperature salt mist and $50^{\circ} \mathrm{C}$ chamber with $5 \%$ $\mathrm{NaCl}$ solution. The photographic documentation of the samples before and after the corrosion load is shown in Fig. 7 and Fig. 8.

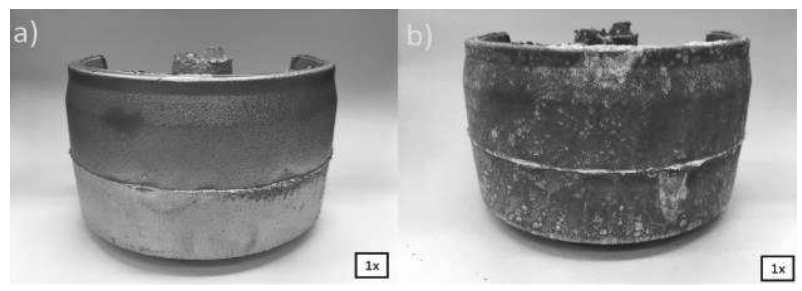

Fig. 7 Experimental samples - casting No. 1 a) before the corrosion load, b) after corrosion load

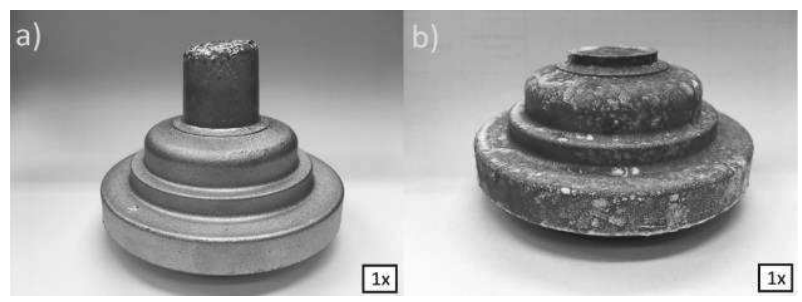

Fig. 8 Experimental samples - casting No. 2 a) before the corrosion load, b) after corrosion load

\subsection{Microscopic analysis}

The samples were subjected to microscopic analysis to evaluate the corrosion attack of the castings. Metallographic samples were prepared for this analysis and the surface condition of the samples before and after the corrosion load was evaluated using an Olympus LEXT OLS 3100 confocal laser microscope. The image analysis of the sample surface (Fig. 11, 13, 16, 18) was used for the evaluation.

\section{Casting No. 1}

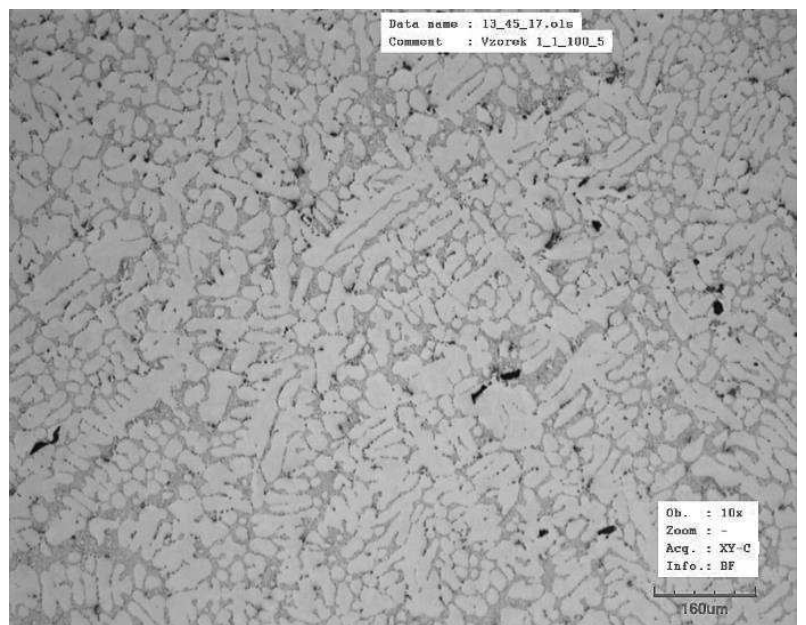

Fig. 9 Casting No. 1 structure

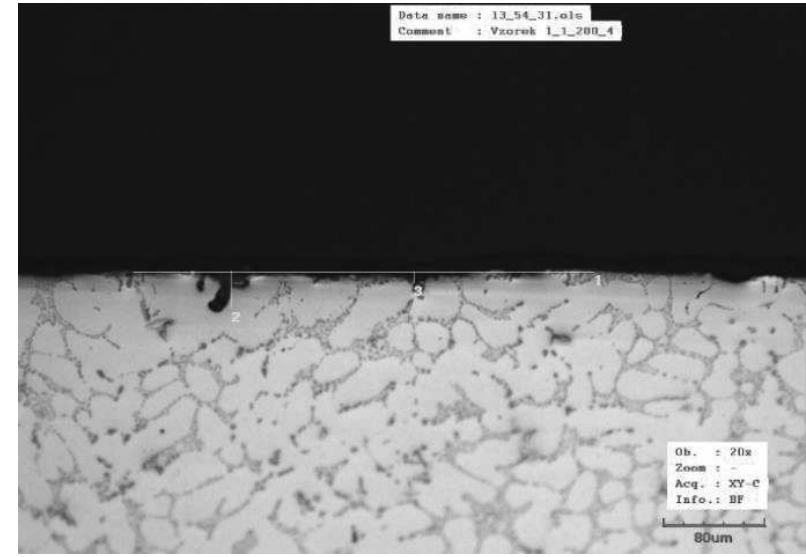

Fig. 10 Casting No. 1 surface before the corrosion load

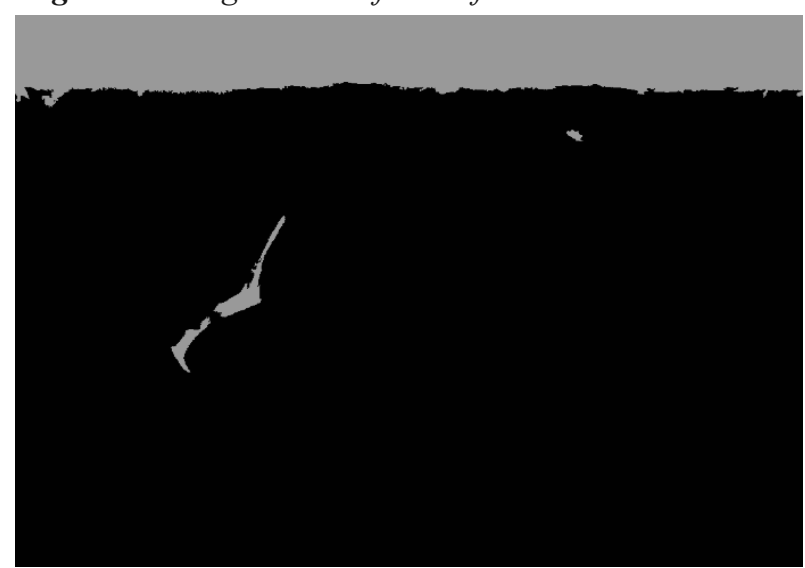

Fig. 11 Casting No. 1 surface before the corrosion load

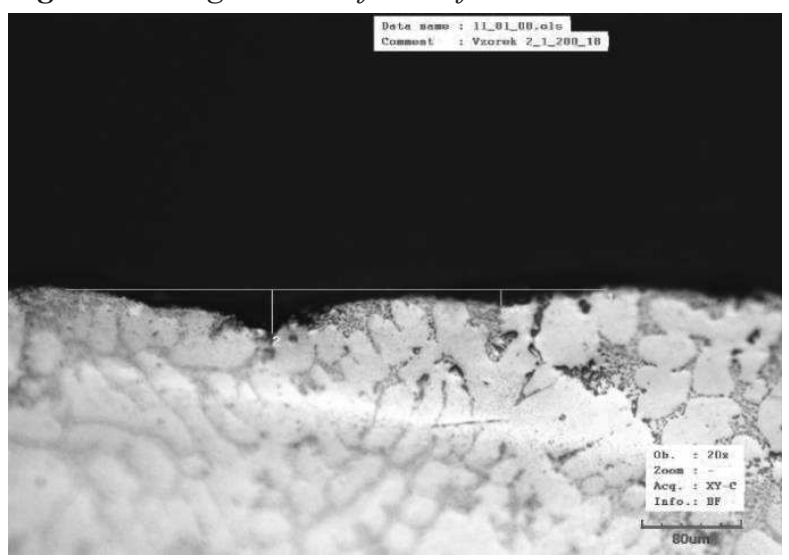

Fig. 12 Casting No. 1 surface after the corrosion load

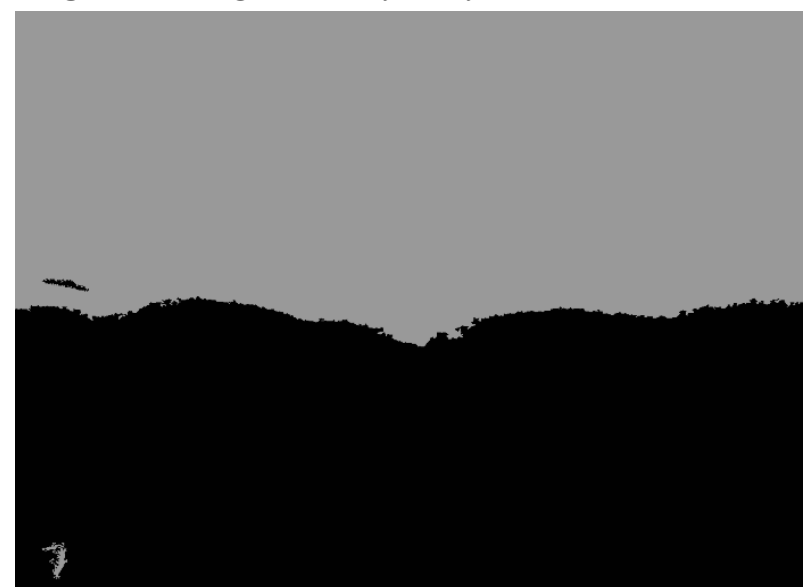

Fig. 13 Casting No. 1 surface after the corrosion load 
Within the microscopic evaluation, the basic structure of the casting, which is typical for the AlSi7Mg0.3 alloy, was observed. In the structure, different sized pores have been identified, which can be described as common interdendritic porosity. Otherwise, the effect of increased Fe content on one of the castings did not show up. Subsequently, there is photo documentation of the changes on the surface of castings due to corrosion. Surface porosity was identified on the surface of the samples, but equally in both samples. Therefore, it is not a phenomenon that occurs only in one of the samples and indicates an increased Fe content. Samples for metallographic cuts were selected from several casting sites. Representatives of each cast were selected for this contribution and publication.

\section{Casting No. 2}

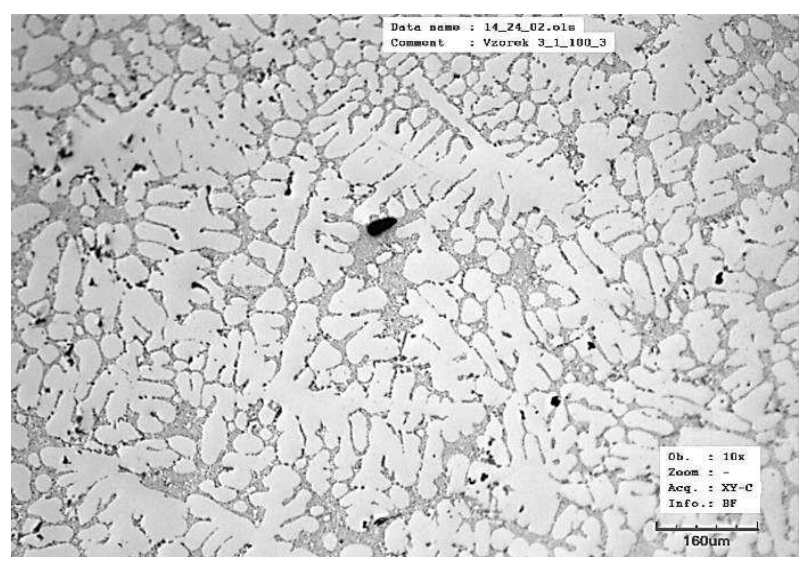

Fig. 14 Casting No. 2 structure

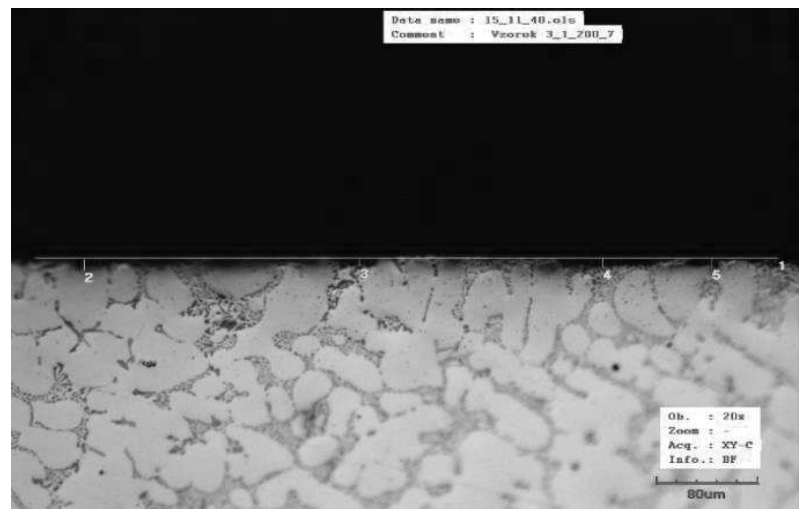

Fig. 15 Casting No. 2 surface before the corrosion load

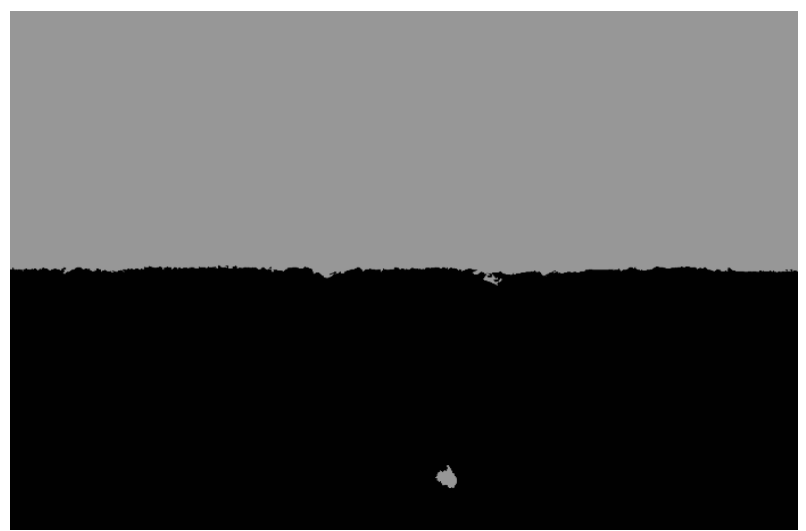

Fig. 16 Casting No. 2 surface before the corrosion load

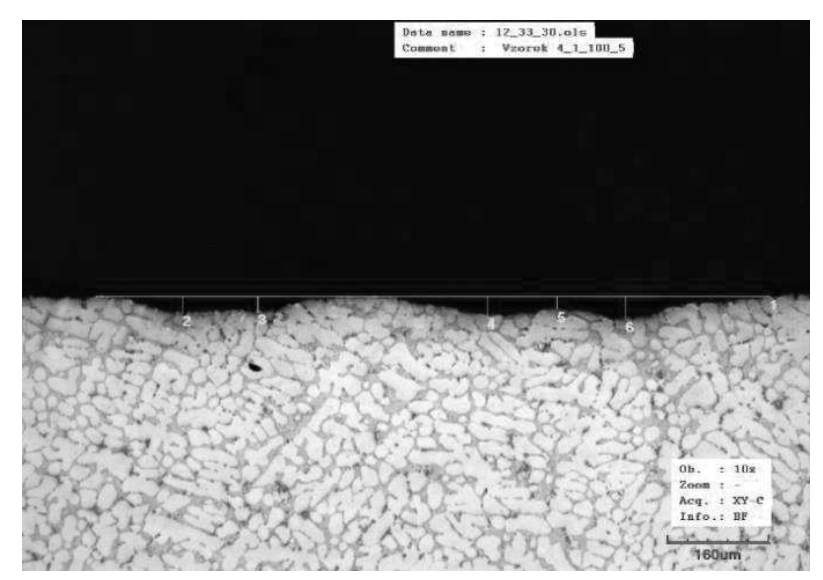

Fig. 17 Casting No. 2 surface after the corrosion load

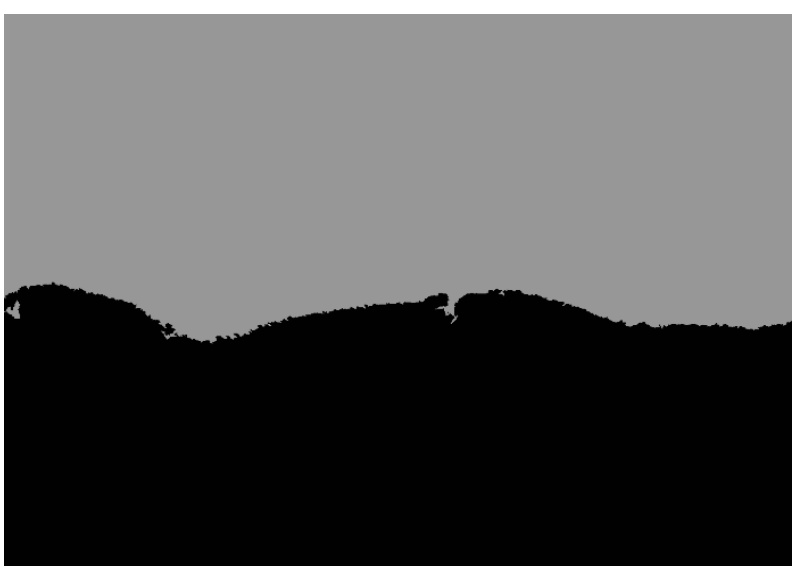

Fig. 18 Casting No. 2 surface after the corrosion load

Within the analysis, were performed measurements from the surface at the places where surface porosity or other defects occurred (most often it was the porosity or unevenness of the casting surface), which encroached to the material of the casting, respectively into the structure from the surface. The largest defects were $20-30 \mu \mathrm{m}$ the smallest around $5 \mu \mathrm{m}$. In the observed material structure near the sample surface, there were observed no other defects except the surface porosity or the increased presence of the intermetallic phases containing Fe, which could have the influence on the corrosion resistance of the casting.

\section{Conclusion}

If the aluminium surfaces are exposed to atmospheric conditions, a thin oxide layer is formed on the surface to protect the surface from further oxidation. This self-protecting characteristic provides aluminium with high corrosion resistance. Aluminium is highly weather resistant, even in industrial environments where other metals often corrode. It is also corrosion resistant in many acids. Caustics and alkaline substances are among the few that attack the oxide layer and thus cause corrosion of aluminium. While this metal can be safely used in the presence of certain mild alkalis with inhibitors, it is generally true that direct contact with alkaline substances will cause corrosion. In this paper, attention is paid to the corrosion resistance of AlSi7Mg0.3 alloy. In the experiment two 
castings were tested, where one of them was found to have an increased $\mathrm{Fe}$ content compared to the value given in the standard for this particular alloy (ČSN EN 1706). The samples were subjected to corrosion loading in the corrosion chamber with salt mist according to ĆSN EN ISO 9227 (038132) Corrosion tests in artificial atmospheres - Salt spray tests and subsequently, the surface condition was evaluated after this load or the negative influence of increased $\mathrm{Fe}$ content on the corrosion resistance of one of the castings. The results of the microscopic analysis did not show any significant influence of the increased $\mathrm{Fe}$ content on the corrosion resistance of the casting compared to the casting in which Fe was normal. Also, in the material structure, this increased Fe content did not manifest in phases that would indicate increased Fe content. Thus, it can be stated that the effect of higher Fe content $(0.319$ [wt. \%]) on the corrosion resistance of the casting was not proved by microscopic analysis of the casting surface.

\section{Acknowledgment}

This article is published for support UJEP-IGA-TC2019-48-02-2 - Creative activity projects - Internal Grant Agency J. E. Purkyně University in Ústí nad Labem.

\section{References}

[1] KOLEKTIV MAĎARSKÝCH

ČESKOSLOVENSKÝCH NĚMECKÝCH A POLSKÝCH AUTORŮ (1969). Př́ručka o hliniku. Praha 1: SNTL

[2] MICHNA, Š., MICHNOVÁ, L. (2014). Neželezné kovy. Ústí n/L: PrintPoint Praha, s.r.o.

[3] MICHNA, Š., LUKÁČ, I., OČENÁČEK, V., KOŘENÝ, R., DRÁPALA, J., SCHNEIDER, H., MIŠKUFOVÁ, A., a kol. (2005). Encyklopedie hliníku. Prešov, Adin, s.r.o., ISBN 80-89041-4

[4] KOCICH, J. TULEJA, S. (1989). Korózia a ochrana kovov. Alfa - Vydavatel'stvo technickej a ekonomickej literatúry Bratislava.
[5] MONDOLFO L. F. (1976). Aluminum alloys: structure and properties. London, London ; Boston : Butterworths, ISBN 04-08706-80-5

[6] DAVIS, J., R. (1999). Corrosion of Aluminum and Aluminum Alloys. ASM International

[7] VOJTĚCH, D. (2006). Kovové materiály. KANAG-TIST, s.r.o., VŠCHT Praha

[8] BOLIBRUCHOVÁ, D., TIllovÁ, E. (2005). Zlievarenské zliatiny Al-Si. Žilina: EDIS - vydavatel'stvo ŽU

[9] HREN, I., SVOBODOVA, J., MICHNA. Š. (2018). Influence of Al5FeSi phases on the cracking of castings at Al-Si alloys. Archives of Foundry Engineering, Vol. 18, No. 4, pp. 120-124

[10] VOJTĚCH, D., KUČERA, V. (2017). Influence of the Heat Treatment on Corrosion Behaviour and Mechanical Properties of the AA 7075 Alloy. Manufacturing Technology, Vol. 17, No. 5, pp. 747752

[11] FOUSOVÁ, M., DVORSKÝ, D., VOJTĚCH, D. (2017). Corrosion Properties of AlSi10Mg Alloy Prepared by Gravity Casting and 3D Printing Technology. Manufacturing Technology, Vol. 17, No. 6, pp. 847-853

[12] BOLIBRUCHOVÁ, D., BRŮNA, M. (2017). Impact of the Elements Affecting the Negative IronBased Phases Morphology in Aluminium Alloys Summary Results. Manufacturing Technology, Vol. 17, No. 5, pp. 675-679

[13] PODPROCKÁ, R., BOLIBRUCHOVÁ, D. (2018). The Role of Manganese in the Alloy Based on Al-Si-Mg with Higher Iron Content. Manufacturing Technology, Vol. 18, No. 4, pp. 650-654

[14] ČSN 424332 Slitina hliníku na odlitky 424332 $\mathrm{AlSi} 7 \mathrm{Mg}(\mathrm{Fe})$

[15] ČSN EN ISO 9227 (038132) Korozní zkoušky v umělých atmosférách - Zkoušky solnou mlhou 